\title{
Assessment of Genetic Variability and Direct-Indirect Contribution of Post-Anthesis Traits to the Grain Yield in Bread Wheat (Triticum aestivum) at Different Sowing Dates
}

\author{
Sami Ul-Allah ${ }^{1 *}$, Asad Azeem ${ }^{1}$, Ahmad Sher ${ }^{1}$, Muhammad Ijaz ${ }^{1}$, Abdul Sattar ${ }^{1}$, Muhammad Asif Saleem ${ }^{2}$, Memoona \\ Bibi $^{1,3}$, Nasir Abbas ${ }^{1}$ and Mubshar Hussain ${ }^{4}$ \\ ${ }^{1}$ College of Agriculture, Bahauddin Zakariya University, Bahadur Sub-Campus Layyah, Pakistan \\ ${ }^{2}$ Department of Plant Breeding and genetics, FAS\&T, Bahauddin Zakariya University, Multan, Pakistan \\ ${ }^{3}$ Department of Plant Breeding and Genetics, University of Agriculture, Faisalabad, Pakistan \\ ${ }^{4}$ Department of Agronomy, FAS\&T, Bahauddin Zakariya University, Multan, Pakistan \\ *For correspondence: samipbg@bzu.edu.pk \\ Received 25 March 2021; Accepted 11 May 2021; Published 10 June 2021
}

Abstract

In cotton-wheat cropping system of Pakistan, sowing of wheat is delayed which results in a heavy loss to the farmers. To this end, a two-year field experiment was conducted to i) asses the performance of genotypes under late sowing ii) heritability and genetic association of different traits under normal and late sowing for their use in the breeding programs. Experimental factors included 20 diverse wheat genotypes (16 advance lines and 04 approved varieties) factorially combined with two sowing dates i.e., normal sowing (11 and 13 November in 2018 and 2019, respectively) and late sowing (09 and 11 December in 2018 and 2019, respectively). The results revealed a highly significant $(P<0.01)$ effect of genotype and sowing date on all the post-anthesis studied traits and the interaction of the two factors was also significant $(P<0.01)$ for all the traits except number of spikelets per spike. Contribution of sowing dates was more in overall variation of different post-anthesis traits than genotypes and their interaction. With respect to the performance, genotype 9725 performed best in both early and late sowing, but a reduction of $26 \%$ in the grain yield was observed due to late sowing, whereas the grain yield of Miraj-2008 was comparatively lower but showed a reduction of only $17 \%$ due to late sowing. Number of tillers per plant and biological yield showed a highly significant $(P<0.01)$ correlation $(\mathrm{r}=0.38$ and 0.72 , respectively) with grain yield under normal conditions, but path analyses revealed that number of tillers per plant showed association indirectly through biological yield and its direct effect is only one third of the total effect. Under late sowing, association of number of tillers turned non-significant and direct effect become negative which showed complicated association of this trait under normal and late sowing. High broad sense heritability $\left(\mathrm{H}^{2}>75 \%\right)$ of all the traits suggests a good genetic gain in breeding program by using these traits. As different genotypes performed best for different yield related traits, therefore a breeding program with a careful crossing plan should be developed to pyramid the genes for different traits for the development of genotypes adapted to late sowing. (C) 2021 Friends Science Publishers

Keywords: Late sowing; Wheat breeding; Path analysis; Heritability

\section{Introduction}

Wheat is the major cereal crop of the world and used as a staple crop to feed the peoples of the world. It occupies the central position in the global cropping pattern and also in the agricultural policies. It dominates all the crops due to its extensive cultivation and higher production. Wheat is a photoperiod sensitive crop and its reproductive phase starts in late February and early March and matures in the late April to mid-May irrespective of sowing dates especially in plain areas of South Asia. In late sown crop, temperature is low, which results in poor and delayed germination (Shah et al. 2019) and results in poor crop stand. Moreover, late sown plants can accumulate less biomass compared to early grown crop at the onset of reproductive phase due to a shorter crop cycle (Tahir et al. 2009; Porker et al. 2020) which results in less photosynthetic assimilates and lower yield. Additionally, increasing in the temperature at the onset of reproductive stage of late sown wheat shortens the crop duration (Mo et al. 2016) resulting in less assimilates production for accumulation in the grains. Due to specific cropping patterns of the area, farmers face lower yields which not only results in lower profitability of the poor farmers but also effects on the global food security. Even some farmers are replacing wheat with some other non-food crops to get maximum profits (Gaba 2018) and putting

To cite this paper: Ul-Allah S, A Azeem, A Sher, M Ijaz, A Sattar, MA Saleem, M Bibi, N Abbas, M Hussain (2021). Assessment of genetic variability and direct-indirect contribution of post-anthesis traits to the grain yield in bread wheat (Triticum aestivum) at different sowing dates. Intl J Agric Biol 26:193-200 
pressure on food security. But on the other hand, higher production of staple crops is essential to feed the everincreasing world population.

Late sowing of wheat significantly affects plant height, tillering, spikes per plant, spikelets per spike and grain weight which ultimately leads to lowers yield (Wajid et al. 2004; Sial et al. 2010). It is estimated that delayed sowing (late December) results in the loss of up to $38 \%$ reduction in the grain yield (Baloch et al. 2012). Late sowing of wheat affects grain yield and its components by affecting crop growth rate due to frost injury at germination stage (Shah et al. 2019) and heat stress at booting and spike initiation stage (Ihsan et al. 2016). Furthermore, heat stress at anthesis of late sown crop disturbs plant physiological and biochemical processes and results in poor growth with a short life cycle. Telfer et al. (2018) conducted a multi-environment experiment to investigate the effect of high temperature during anthesis and grain filling period and reported that with increase in each ${ }^{\circ} \mathrm{C}$ after $30^{\circ} \mathrm{C}$ resulted in a reduction of $302 \mathrm{~kg} \mathrm{ha}^{-1}$ and $161 \mathrm{~kg} \mathrm{ha}^{-1}$ at anthesis and grain filling stages, respectively. They further suggested to using field trails for the evaluation of heat tolerant germplasm. Talukder et al. (2014) reported that heat stress at heading stage shorten the post heading duration of crop which results in the reduction of final grain yield. Variation in the genotypes in response to late sowing for yield and other components have been well documented (Tahir et al. 2009; Talukder et al. 2014; Telfer et al. 2018; Porker et al. 2020). But only a little effort has been placed to select the traits which response best to late sowing for selection of wheat genotypes. Exact knowledge of plant architecture, its response to environmental conditions and its heritability is necessary for development of environment responsive genotypes.

Knowledge of post anthesis plant architecture (Senapati and Semenov 2019; Ullah et al. 2020) and association of morphological traits especially yield components with final grain yield (Talukder et al. 2014; UlAllah et al. 2018) is very important in developing specific environment responsive genotypes because plant changes its morphological traits in response to environmental stress. By this we can assess contribution of different traits to the yield and their sensitivity to environmental stress like heat stress in case of late sowing, which will help in selection of the best genotypes. Although there are many studies which describe the effect of late sowing on yield and its components, but there is lack of knowledge about the plant maturity traits, association of the post anthesis traits with grain yield and their direct and indirect effects for the development of the genotypes best adopted to late sown conditions. Moreover, a little is known about the heritability's of different traits of the plant architecture adapted to specific (timely or late) sowing date. Therefore, objective of this study was to investigate the effect of late sowing on the traits of mature wheat plant and their association with final grain yield along with direct and indirect effects. This study could help to facilitate the optimal selection criteria for development of wheat genotypes adapted to late sowing.

\section{Materials and Methods}

\section{Experimental site}

The field experiment was conducted in the experimental area of the College of Agriculture, Bahauddin Zakariya University, Bahadur Sub-Campus Layyah, Pakistan during the wheat season of 2018-19 and 2019-20. The experimental soil was characterized as sandy loam with a bulk density of $1.29 \mathrm{Mg} \mathrm{m}^{-3}$ and $\mathrm{pH}$ was 8.2 . The soil has medium fertility i.e., $\mathrm{N}$ contents $435 \mathrm{mg} \mathrm{kg}^{-1}, \mathrm{P}$ contents 6.8 $\mathrm{mg} \mathrm{kg}{ }^{-1}$ and $\mathrm{K}$ contents $123 \mathrm{mg} \mathrm{kg}^{-1}$. This area falls in a category of subtropical climate with warm summers and cool winter with an average rainfall of $\leq 200 \mathrm{~mm}$. During the experimental seasons, the weather conditions of experimental location were presented in Fig. S1.

\section{Plant material and experimental design}

The seed of twenty wheat genotypes (approved varieties and advance lines) was obtained from different research institutes of Pakistan (Table S1) for the first year of crop while, for the second year, self-seed was harvested and reused. The twenty wheat genotypes were sown in two dates of sowing i.e., normal sowing (11 and 13 November in 2018 and 2019, respectively) and late sowing (09 and 11 December in 2018 and 2019, respectively). The experiment was laid out in a randomized complete block design (RCBD) under factorial arrangements with three replications. Factors included 20 wheat genotypes (Table 1) and two sowing dates each in 2018 and 2019. For each genotype, 5 rows, each six feet long were sown with row-torow distance of $30 \mathrm{~cm}$ and plant to plant distance of $15 \mathrm{~cm}$. Five irrigation (pre-sown irrigation, tillering, joint formation, booting and milking stage) were applied to meet the moisture requirements of the crop. Fertilizer was applied at the rate of $120(\mathrm{~N}): 90(\mathrm{P}): 60(\mathrm{~K}) \mathrm{kg} \mathrm{ha}^{-1}$ while source of the fertilizer were Urea, Diamonium Phosphate and Sulphate of Potash. Weeds were controlled by applying Buctril Super 60\% (Bayer Pakistan Private Limited) EC at tillering stage.).

\section{Data collection}

Data were collected from selected 10 guarded plants from each experimental unit. Plant height was measured with the help of a meter rod (soil surface to the tip of awns) of the mother tiller of the selected plants followed by average calculation. From the selected plants, data for number of tillers per plant (counted manually), spike length (with the help of measuring tape, excluding the awns), number of spikelets per spike (counted manually) were recorded. For 
biological yield, selected plants were harvested, and sun dried until constant weight and average plant biomass was calculated as an average of 10 plants. After that, the plants were threshed manually, seeds were separated from straw and average grain yield per plant was calculated as an average of ten plants.

Reduction in the performance of different traits of wheat genotypes due to late sowing was calculated by the following formula:

$$
\text { Reduction }(\%)=\left\{\frac{\text { Perfromance in normal sowing }}{\text { Perfromance in late sowing }}-1\right\} \times 100
$$

\section{Statistical analyses}

Collected data were statistically analyzed for analyses of variance followed by comparison of the means by Tukey's test using Statistix 8.1. Genotypic correlation (Fisher 1992) was calculated among yield and yield contributing traits. Direct and indirect effects of correlation were determined by the path coefficient analyses as described by (Dewey and Lu 1959). Standard Broad-sense heritability (Schmidt et al. 2019) was calculated for all the studied traits grown under normal and later sowing separately as ratio of genotypic variance to phenotypic variance as given below.

$$
\text { Heritability Broadsense }\left(h_{b s}^{2}\right)=\frac{G V}{P V}
$$

Where, GV and PV stands for genotypic variance and phenotypic variance and calculated as

$$
\text { Genotypic vairnace }(G V)=(M S G-M S E) / r
$$

Where, MSG stands for mean square of genotypes and MSE stands for mean square error

$$
\text { Phenotypic variance }(P V)=G V+M S E
$$

Figures were prepared using Sigmaplot v. 12.

\section{Results}

\section{Morphological traits}

Analyses of variance revealed that all the traits were significantly $(P<0.01)$ affected by genotypes and sowing dates and the interaction of the two factors was significant $(P<0.01)$ for all the traits except number of spikelets per spike (Table 1). Plant height for normal sowing ranged from 66 (Miraj-2000) to $101 \mathrm{~cm}$ (Syn-42) while for late sowing it ranged from 58 (9868) to $82 \mathrm{~cm}$ Syn-46). Maximum reduction in plant height $(28 \%)$ was observed for the genotype Syn-42 while the minimum was observed in the genotype Syn-31 i.e., 3.4\%. Number of tillers per plant for normal sowing ranged from 02 Miraj-2000) to 05 (Bhakkar2002) and for late sowing it ranged from 2.6 (Bhakkar2002) to 3.8 (AS-2002). Maximum reduction for number of tillers was observed in the genotype Bhakkar 2002. Spike length for normal sowing ranged from $8.8 \mathrm{~cm}$ (Syn-31) to
$12.16 \mathrm{~cm}$ Syn-33) and for late sowing it ranged from $7.2 \mathrm{~cm}$ (Syn-40) to $9.7 \mathrm{~cm}$ (G 9782). Maximum reduction in late sowing was observed in the genotype Syn-33 (29\%) and minimum was observed in the genotype Syn-21 (5\%). In normal, sowing number of spikelets per spike ranged from 16 (G Syn-50) to 20 (Genotype 9733) for normal sowing and from 12 Miraj-2008) to 15 (Syn-33) for late sowing. Maximum reduction (37\%) in number of spikelets per spike due to late sowing was observed the in the genotype AS2002 and minimum (19.8\%) was observed in the genotypes Syn-33 and Syn-40 (Fig. 1; Table 3).

Biological yield and grain yield were the two traits that were highly affected by the late sowing. In the normal sowing biological yield per plant ranged from $11.5 \mathrm{~g}$ (9733) to $20 \mathrm{~g}$ (9725) while for late sowing it ranged from $7.7 \mathrm{~g}$ (Syn-40) to $15 \mathrm{~g}$ (9725). For biological yield maximum reduction $(38 \%)$ was observed in the genotype Syn-40 and minimum reduction $(23 \%)$ was observed in the genotype Syn-37. Average grain yield of single wheat plant ranged $4.5 \mathrm{~g}$ ( $\mathrm{G} 9733$ ) to $9 \mathrm{~g}$ (9725) in normal sowing and $3 \mathrm{~g}$ (Genotype 9733) to $5.9 \mathrm{~g}$ (Genotype 9782) in late sowing. For grain yield maximum reduction $(42 \%)$ was observed in the genotype Syn-33 and minimum reduction (25\%) was observed in the genotype Syn-31 (Fig. 2; Table 3).

\section{Heritability}

Heritability is a statistical measure of inheritance. Broad sense heritability was measured for all the studied traits separately for early and late sown genotypes. Under normal sowing maximum heritability was observed for biological yield $(92.88 \%)$ and grain yield $(92.80 \%)$ and under late sowing, it is reduced to $83 \%$ and $74 \%$, respectively. But for the spike length and spikelets per spike heritability increased and in late sowing it was 93.12 and $90.12 \%$, respectively (Table 2).

\section{Correlation and path analyses}

Correlation coefficients were calculated to measure the association between different traits. It was observed that overall association weaken in late sown wheat. Under normal sowing maximum correlation was observed between grain yield and biological yield $(r=0.72)$ followed by plant height and spike length $(r=0.63)$. Other significant correlations were observed between plant height and number of spikelets per spik, between number of tillers per plant and biological yield/grain yield. In normal sowing negative correlation $(r=-0.18)$ was observed between grain yield and spikelets per spike which turn to non-significant in late sown wheat. In late sown wheat maximum correlation was observed between grain yield and biological yield ( $r=$ 0.65) (Table 4).

Path coefficient analysis dissects the correlation into direct and indirect effects. As the value of the correlation coefficients changed over sowing dates, similarly direct and 
Table 1: Mean squares of different morphological and yield related traits of 20 wheat genotypes under late and normal sowing dates

\begin{tabular}{|c|c|c|c|c|c|c|c|}
\hline Source of variance & $\mathrm{df}$ & Plant height & No. of tiller/plant & Spike length & No. of spikelet/spike & Biological yield/plant & Grain yield/plant \\
\hline Year & 1 & $0.32^{\mathrm{ns}}$ & $2.1^{\mathrm{ns}}$ & $0.64^{\mathrm{ns}}$ & $20.12^{\mathrm{ns}}$ & $0.24^{\mathrm{ns}}$ & $1.02^{\mathrm{ns}}$ \\
\hline Sowing date (S) & 1 & $717.90 * *$ & $136.68 * *$ & $124.93 * *$ & $3658.21 * *$ & $16.38 * *$ & $824.18 * *$ \\
\hline Genotype (G) & 19 & $31.60 * *$ & $7.06^{* * *}$ & $3.33 * *$ & $279.16^{* *}$ & $1.62 * *$ & $4.14 * *$ \\
\hline
\end{tabular}

SD1 - sowing date 1 (normal sowing); SD-2 - Sowing date 2 (late sowing)

*-Significant at $5 \%$ probability; $* *$ significant at $1 \%$ probability; ns- non-significant

Table 2: Heritability values (broad sense) of yield and related traits of wheat at two different sowing dates as obtained in 2018-19 and 2019-20

\begin{tabular}{|c|c|c|c|c|c|c|c|c|c|c|c|c|}
\hline Sowing dates & Plant heig & & No. of till & r/plant & Spike len & & No. of spi & let/spike & Biologic: & ield/plant & Grain yie & d/plant \\
\hline Year & 2018-19 & 2019-20 & 2018-19 & $2019-20$ & 2018-19 & 2019-20 & 2018-19 & $2019-20$ & 2018-19 & 2019-20 & $2018-19$ & 2019-20 \\
\hline Normal sowing & 93.22 & 92.54 & 93.90 & 91.70 & 81.94 & 80.1 & 93.00 & 90.94 & 91.62 & 88.14 & 85.14 & 82.88 \\
\hline Late sowing & 84.12 & 82.36 & 72.72 & 77.12 & 93.08 & 93.16 & 86.00 & 84.12 & 77.00 & 73.32 & 92.24 & 89.12 \\
\hline
\end{tabular}
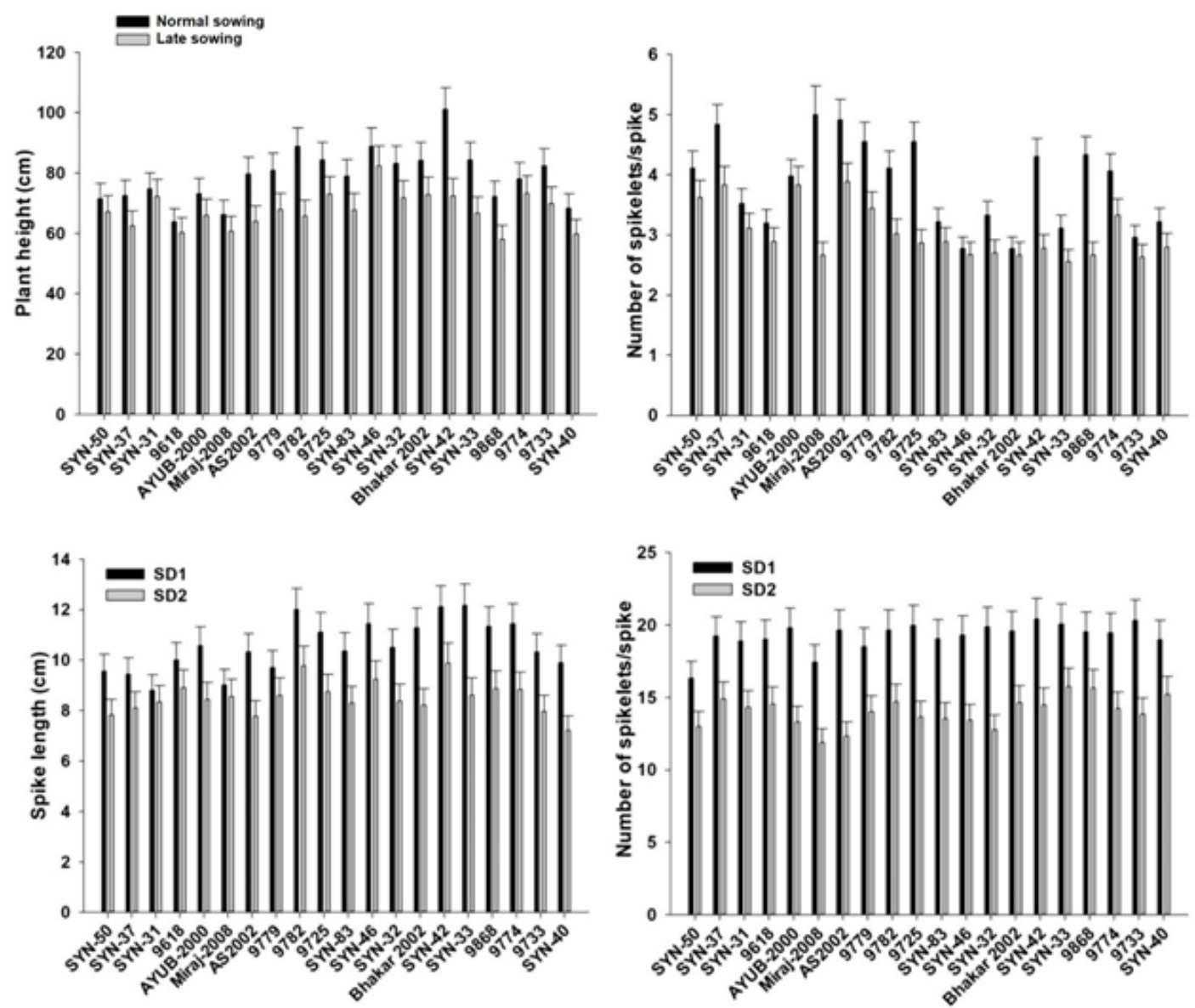

Fig. 1: Effect of genotype and sowing date on different morphological traits of wheat. (Data are average of two years and three replications $\pm \mathrm{SE}$ )

indirect effects also changed (Fig. 3, 4). Association of different studied traits with yield was dissected and it was observed that most of the indirect effects were very small. Under normal sowing, correlation of number of tillers was 0.38 but path analyses revealed that its direct effect was only 0.12 whereas indirect effect of number of tillers via biological yield was 0.26. Magnitude of other indirect effects was very small and direct effects were relevant to the overall correlation (Fig. 3). In late sowing, number of tillers had only a very weak association with yield $(r=0.03)$, but its direct effect was -0.11 and its indirect effect via biological yield was 0.11 . In late sown genotypes, spike length has a significant association with yield $(r=0.21)$ but its direct effect was only 0.05 and its indirect effect via biological yield was 0.19. Magnitude of other indirect effects was very small (Fig. 4). 
Genetic Variability and Direct-indirect Associations in Wheat / Intl J Agric Biol, Vol 26, No 1, 2021

Table 3: Reduction (\%) in the performance of various traits of wheat genotype due to late sowing

\begin{tabular}{|c|c|c|c|c|c|c|}
\hline Traits Genotypes & Plant height & No. of tiller/plant & Spike length & No. of spikelet/spike & Biological yield/plant & Grain yield/plant \\
\hline SYN-50 & 6.00 & 18.26 & 20.46 & 11.84 & 28.50 & 31.86 \\
\hline SYN-37 & 13.98 & 14.12 & 22.58 & 20.69 & 22.99 & 25.98 \\
\hline SYN-31 & 3.45 & 5.31 & 24.20 & 11.65 & 28.86 & 31.17 \\
\hline 9618 & 5.41 & 11.00 & 23.52 & 9.69 & 29.40 & 25.51 \\
\hline AYUB-2000 & 9.74 & 20.18 & 32.66 & 3.61 & 30.26 & 39.46 \\
\hline Miraj-2008 & 8.38 & 5.03 & 31.84 & 46.67 & 32.59 & 17.91 \\
\hline AS2002 & 19.68 & 24.69 & 37.29 & 20.84 & 36.20 & 31.74 \\
\hline 9779 & 16.08 & 11.24 & 24.46 & 24.38 & 29.93 & 31.29 \\
\hline 9782 & 25.91 & 18.59 & 25.14 & 26.44 & 29.13 & 30.55 \\
\hline 9725 & 13.53 & 21.24 & 31.55 & 37.12 & 25.53 & 26.39 \\
\hline SYN-83 & 14.20 & 19.94 & 28.92 & 10.25 & 41.51 & 33.96 \\
\hline SYN-46 & 7.13 & 19.23 & 30.36 & 3.72 & 37.29 & 29.75 \\
\hline SYN-32 & 13.73 & 20.12 & 35.69 & 18.84 & 33.56 & 41.36 \\
\hline Bhakar 2002 & 13.44 & 27.11 & 25.19 & 3.84 & 33.95 & 36.90 \\
\hline SYN-42 & 28.37 & 18.39 & 29.04 & 35.40 & 29.39 & 38.42 \\
\hline SYN-33 & 20.76 & 29.26 & 21.38 & 17.90 & 35.00 & 41.92 \\
\hline 9868 & 19.69 & 21.76 & 19.79 & 38.46 & 35.69 & 36.81 \\
\hline 9774 & 6.13 & 22.81 & 26.89 & 17.97 & 30.88 & 35.54 \\
\hline 9733 & 15.24 & 22.80 & 31.80 & 10.94 & 31.13 & 40.48 \\
\hline SYN-40 & 12.51 & 27.14 & 19.83 & 13.04 & 38.42 & 36.26 \\
\hline
\end{tabular}

Table 4: Correlation among morphological and yield related traits of wheat genotypes under late and normal sowing

\begin{tabular}{|c|c|c|c|c|c|c|}
\hline Traits & Plant height & No. of tiller/plant & Spike length & No. of spikelet/spike & Biological yield/plant & Grain yield/plant \\
\hline Plant height & 1 & $-0.15^{n s}$ & $0.46 * *$ & $-0.08^{n s}$ & $0.01^{\text {ns }}$ & $-0.11^{\mathrm{ns}}$ \\
\hline No. of tiller & $0.01^{\mathrm{ns}}$ & 1 & $-0.08^{n s}$ & $-0.08^{n s}$ & $0.18^{\text {ns }}$ & $0.033^{\text {ns }}$ \\
\hline Spike length & $0.63 * *$ & $-0.09^{\mathrm{ns}}$ & 1 & $0.033^{\text {ns }}$ & $0.29 *$ & $0.21 *$ \\
\hline No. of spikelet & $0.40 * *$ & $-0.10^{\mathrm{ns}}$ & $0.51 * *$ & 1 & $-0.01^{n s}$ & $-0.09^{n s}$ \\
\hline Biological yield & $0.17^{\mathrm{ns}}$ & $0.39 * *$ & $0.06^{\mathrm{ns}}$ & $-0.15^{\mathrm{ns}}$ & 1 & $0.65 * *$ \\
\hline Grain yield & $0.06^{\mathrm{ns}}$ & $0.38 * *$ & $0.04^{\mathrm{ns}}$ & $-0.18^{*}$ & $0.72 * *$ & 1 \\
\hline
\end{tabular}
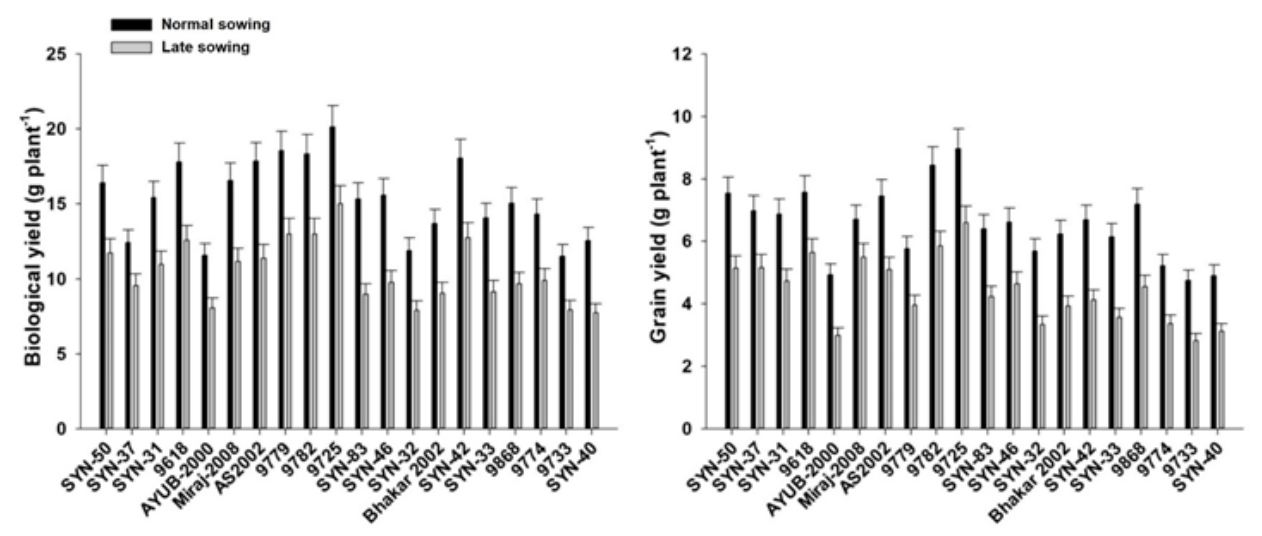

Fig. 2: Effect of genotype and sowing date on biological and grain yield of wheat (Data is an average of two years and three replications $\pm \mathrm{SE}$ )

\section{Discussion}

In cotton-wheat system, last picking of cotton is done in November, and after the harvest of the cotton sticks, wheat is often sown in December. Growth and production of wheat crop is highly hampered by late sowing due to shorten of growth period coupled with terminal heat stress (Viswanathan and Khanna-Chopra 2001; Dhyani et al. 2013: Zain et al. 2017; Sisson et al. 2018). In current study all the traits were affected by sowing date and genotype but variation due to sowing date was considerably high than genotypes and their interaction which is evident from the higher mean square values of sowing dates for different traits (Ul-Allah et al. 2014). In current study, a significant reduction in the value of morphological traits was observed. As wheat is a photoperiod sensitive crop (Aslam et al. 2017; Whittal et al. 2018) due to which its growth and development along with size of morphological attributes is highly dependent on duration of crop cycle. Crop of both sowing dates matured in April but difference in the sowing was one moth, therefore late sown wheat received less time for growth and development and value of morphological 


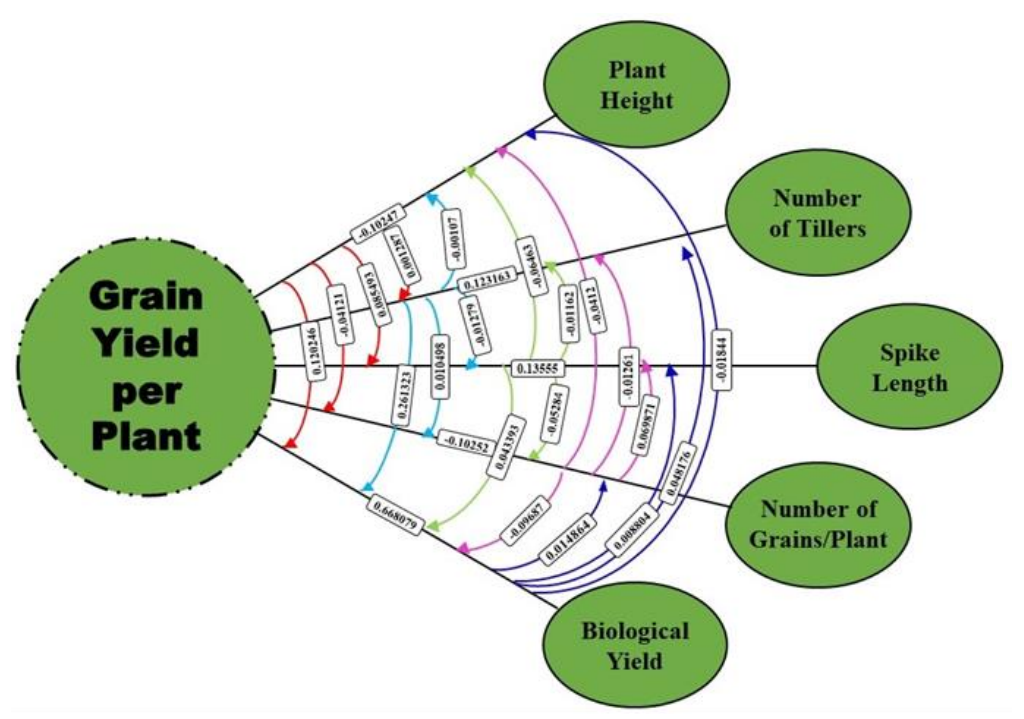

Fig. 3: Path diagram of grain yield different traits affecting grain yield under normal sowing

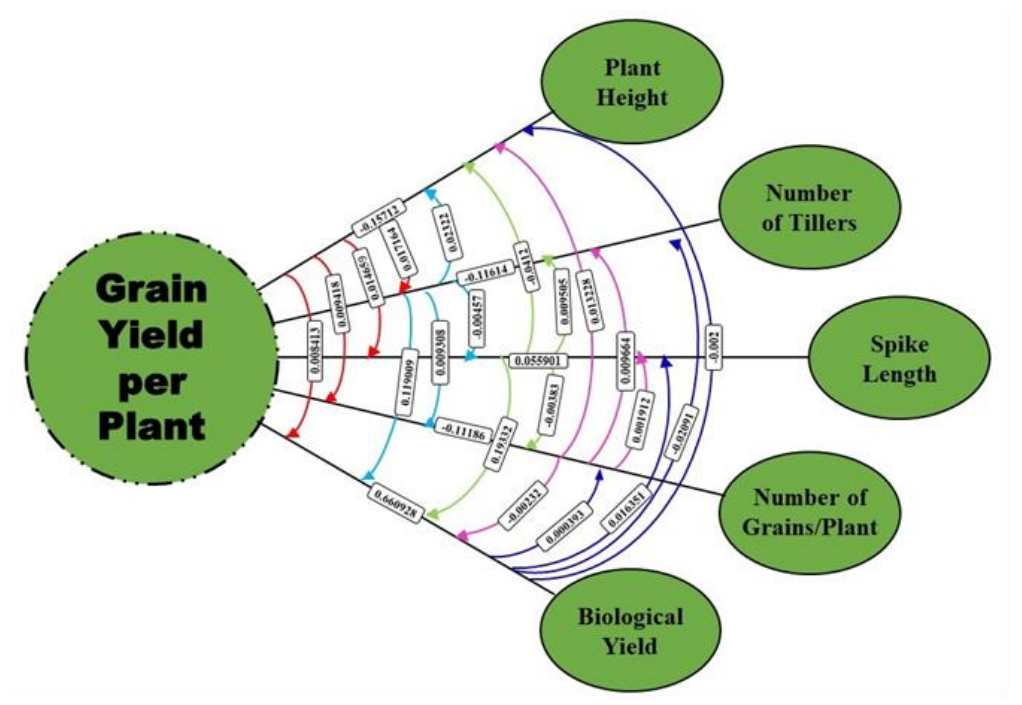

Fig. 4: Path diagram of grain yield different traits affecting grain yield under late sowing

traits remained relatively low. Moreover, in normal sown wheat anthesis completes until the late February, when temperature is moderate, but in late sown wheat anthesis completes in late March where temperature was relatively high and cause less seed setting (Akhter and Islam 2017; Hütsch et al. 2019). Hütsch et al. (2019) reported that with high temperature, sink capacity of wheat decreased which results in less seed setting with smaller seeds and results in lower harvest index.

In current study, plant biomass and grain yield were reduced which attributed to both i.e., less crop duration and terminal heat stress. As maturity of late sown crop was nearly same as early sown, therefore plant received less time for biomass development and assimilates accumulation (Chakrabarti et al. 2011; Whittal et al. 2018; Aiqing et al. 2018) resulting in lower biomass and grain yield. But some genotypes resist this reduction in biomass and grain yield to some extent due to better genetic makeup and some possible escape mechanism. Aiqing et al. (2018) reported that genotypes escape from terminal heat stress during early reproductive stage by altering their anthesis time and early gametogenesis. They reported 11 genotypes, which flowered during cooler hours of the day to avoid heat stress. Another possible mechanism of relative higher yield of some genotypes under late sowing may be attributed to better nutrient use efficiency (Yin et al. 2018) where some genotypes accumulated more assimilate and show less reduction in biomass and grain yield. Therefore, it is suggested that genotypes should be selected very carefully, if the farmers become late in wheat sowing. Moreover, there were different genotypes, which performed best for different traits, which shows 
that genes for various traits are present on different genotypes, which needs to be pyramid for development of late sown adoptive genotypes.

For any breeding program knowledge of association among yield related traits and their heritability are very important for the selection of interested traits. Under normal sowing, heritability of all the traits were more than $80 \%$ and under late sowing, heritability of only number of tillers was $75 \%$ while all other were more than $80 \%$. High value of heritability showed that all the studied traits are valuable for breeding and can result in a significant genetic advance for late sown wheat (Iqbal et al. 2017; Mwadzingeni et al. 2017; Alonso et al. 2018; Balkan 2018) but for the selection of traits further studies may be conducted to confirm the gene action governing these traits as Broad sense heritability estimates cannot predict the type of gene action. Alonso et al. (2018) also suggested that selection of traits with higher heritability increase the genetic progress in next generations. Heritability of some traits increased and for some traits decrease under late sown which mainly attributed to change in the genetic variation among genotypes in two sowing dates. Change in heritability estimates under different sowing dates showed that selection criteria should be reevaluated for different environmental conditions which are supported by the findings of other researchers working on wheat (Eid 2009; Abou-Zaid et al. 2017; Lou et al. 2021).

Most of the traits showed weak association among themselves and also with yield, which make the process of selection complicated. Association was also affected by the sowing dates. For example, correlation coefficient of plant height and spike length was $0.63(P<0.01)$ under normal sowing while in late sowing it was $0.46(P<0.01)$. Likewise, in normal sowing number of tillers were strongly correlated with grain yield $(r=0.38 ; P<0.01)$, while in late sowing association was non-significant. Differences in the association under different sowing dates attributed the genes which changes their expression under different environment (Eid 2009; Abou-Zaid et al. 2017; Lou et al. 2021).

As association for some traits were weak and for some other traits, changes over the environment, therefore, these were dissected into direct and indirect effect to analyze how different traits affect yield directly and indirectly by affecting other attributes. Under normal sowing, number of tillers showed strong correlation with grain yield $(r=0.38$; $P<0.01$ ), but path analyses showed that only $1 / 3$ of this association was direct while other attributed to indirect effect mostly thorough biological yield (Fig. 3). Likewise, under late sowing, a non-significant association i.e., number of tillers with grain yield was observed, but path analyses showed negative direct $(r=-0.11)$ effect of number of tillers on yield (Fig. 4). These changes, attributed to the activation of different type of genes and change in the association of linked traits under different sowing dates (Abou-Zaid et al. 2017; Agrawal et al. 2018; Lou et al. 2021). Agrawal et al. (2018) showed that direct and indirect effects of phenotypic traits and their association changed under normal and late sown chickpea. Lou et al. (2021) reported up to $13 \%$ variation in association of different QTLs with phenotypic nutritional quality traits of wheat under two sowing dates and suggested this change in association linked with the genes which expressed only in stress conditions (Muthusamy et al. 2017; Mahmoud et al. 2020). This change in association and direct and indirect effects necessitate the change in selection criteria for wheat grown on different sowing dates and different environmental conditions.

\section{Conclusion}

Late sowing reduced the grains yield and biomass due to short crop duration and terminal heat stress. Change in the association of morphological traits and grain yield under normal and late sowing necessitate the careful modulation of selection criteria for different environments even at same location. As most of the traits showed significant indirect contribution, therefore, those traits should be considered for maximum selection gains. As different genotypes performed best for different yield related traits, therefore a breeding program with a careful crossing plan should be developed to pyramid the genes for different traits for the development of genotypes adoptive to late sowing.

\section{Acknowledgements}

Authors are thankful to AARI Faisalabad, Department of PBG, university of Agriculture, Faisalabad and Department of PBG, BZU Multan for provision of seed material.

\section{Author Contributions}

S. Ul-Allah contributed to the study conception and design. Material preparation, data collection was performed by $\mathrm{M}$. Bibi, A. Azeem and N. Abbas, analyses were performed by S. Ul-Allah, A. Azeem, MA Saleem and A. Sattar. The first draft of the manuscript was written by S Ul-Allah and A Azeem. A Sher, M Ijaz and M Husnain contributed to execution of the study and reviewed and edited the manuscript. All authors approved the final manuscript.

\section{Conflicts of Interest}

The authors declare that they have no competing interests.

\section{Data Availability}

Not Applicable.

\section{Ethical Approval}

Not applicable. 


\section{References}

Abou-Zaid GG, SM Mostafa, RA El-Refaey (2017). Genotype × Environment Interaction Effects on Heritability and Genetic Advance for Yield and its Components of Some Faba Bean Genotypes. J Plant Prod 8:665-669

Agrawal T, A Kumar, S Kumar, A Kumar, RR Kumar, S Kumar, P Singh (2018). Correlation and path coefficient analysis for grain yield and yield components in chickpea (Cicer arietinum L.) under normal and late sown conditions of Bihar India. Intl J Curr Microbiol Appl Sci $7: 1633-1642$

Aiqing S, I Somayanda, SV Sebastian, K Singh, K Gill, PVV Prasad, SK Jagadish (2018). Heat stress during flowering affects time of day of flowering, seed set, and grain quality in spring wheat. Crop Sci 58:380-392

Akhter N, MR Islam (2017). Heat stress effects and management in wheat. A review. Agron Sustain Dev 37:1-17

Alonso MP, NE Mirabella, JS Panelo, MG Cendoya, AC Pontaroli (2018). Selection for high spike fertility index increases genetic progress in grain yield and stability in bread wheat. Euphytica 214; Article 112

Aslam MA, M Ahmed, CO Stöckle, SS Higgins, FU Hassan, R Hayat (2017). Can growing degree days and photoperiod predict spring wheat phenology? Front Environ Sci 5; Article 57

Balkan A (2018). Genetic variability, heritability and genetic advance for yield and quality traits in M2-4 generations of bread wheat (Triticum aestivum L.) genotypes. Turk J Field Crop 23:173-179

Baloch MS, MA Nadim, M Zubair, IU Awan, EA Khan, S Ali (2012). Evaluation of wheat under normal and late sowing conditions. Pak $J$ Bot 44:1727-1732

Chakrabarti B, SD Singh, S Nagarajan, PK Aggarwal (2011). Impact of temperature on phenology and pollen sterility of wheat varieties. Aust J Crop Sci 5:1039-1043

Dewey DR, KH Lu (1959). A correlation and path-coefficient analysis of components of crested wheatgrass seed production 1. Agron J 51:515-518

Dhyani K, MW Ansari, YR Rao, RS Verma, A Shukla, N Tuteja (2013) Comparative physiological response of wheat genotypes under terminal heat stress. Plant Signal Behav 8; Article e24564

Eid MH (2009). Estimation of heritability and genetic advance of yield traits in wheat (Triticum aestivum L.) under drought condition. Intl J Genet Mol Biol 1:115-120

Fisher RA (1992). Statistical methods for research workers. In: Breakthroughs in Statistics, pp:66-70. Springer, Verlag, Germany

Gaba S (2018). Review of the impacts on biodiversity of land-use changes induced by non-food biomass production. In: Sustainable Agriculture Reviews, Vol. 30, pp:195-212. Springer, Cham, Switzerland

Hütsch BW, D Jahn, S Schubert (2019). Grain yield of wheat (Triticum aestivum $\mathrm{L}$.) under long-term heat stress is sink-limited with stronger inhibition of kernel setting than grain filling. J Agron Crop Sci 205:22-32

Ihsan MZ, FS El-Nakhlawy, SM Ismail, S Fahad, I Daur (2016). Wheat phenological development and growth studies as affected by drought and late season high temperature stress under arid environment. Front Plant Sci 7; Article 795

Iqbal A, IH Khalil, SMA Shah, MS Kakar (2017). Estimation of heritability, genetic advance and correlation for morphological traits in spring wheat. Sarhad J Agric 33:674-679

Lou H, R Zhang, Y Liu, D Guo, S Zhai, A Chen, Y Zhang, C Xie, M You, H Peng, R Liang (2021). Genome-wide association study of six quality-related traits in common wheat (Triticum aestivum L.) under two sowing conditions. Theor Appl Genet 134:399-418

Mahmoud D, R Pandey, L Sathee, M Dalal, MP Singh, V Chinnusamy (2020). Regulation of expression of genes associated with nitrate response by osmotic stress and combined osmotic and nitrogen deficiency stress in bread wheat (Triticum aestivum L.). Plant Physiol Rep 25:200-215
Mo F, M Sun, XY Liu, JY Wang, XC Zhang, BL Ma, YC Xiong (2016). Phenological responses of spring wheat and maize to changes in crop management and rising temperatures from 1992 to 2013 across the Loess Plateau. Field Crops Res 196:337-347

Muthusamy SK, M Dalal, V Chinnusamy, KC Bansal (2017). Genomewide identification and analysis of biotic and abiotic stress regulation of small heat shock protein (HSP20) family genes in bread wheat. $J$ Plant Physiol 211:100-113

Mwadzingeni L, H Shimelis, TJ Tsilo (2017). Variance components and heritability of yield and yield components of wheat under droughtstressed and non-stressed conditions. Aust J Crop Sci 11:1425-1430

Porker K, M Straight, JR Hunt (2020). Evaluation of G $\times E \times$ M interactions to increase harvest index and yield of early sown wheat. Front Plant Sci 11; Article 994

Schmidt P, J Hartung, J Rath, HP Piepho (2019). Estimating broad-sense heritability with unbalanced data from agricultural cultivar trials. Crop Sci 59:525-536

Senapati N, MA Semenov (2019). Assessing yield gap in high productive countries by designing wheat ideotypes. Sci Rep 9; Article 5516

Shah T, S Latif, H Khan, F Munsif, L Nie (2019). Ascorbic acid priming enhances seed germination and seedling growth of winter wheat under low temperature due to late sowing in Pakistan. Agronomy 9; Article 757

Sial MA, MA Arain, MU Dahot, GS Markhand, KA Laghari, SM Mangrio, AA Mirbahari, MH Naqvi (2010). Effect of sowing dates on yield and yield components on mutant-cum-hybrid lines of bread wheat Pak J Bot 42:269-277

Sissons M, D Pleming, JD Taylor, L Emebiri, NC Collins (2018). Effects of heat exposure from late sowing on the agronomic and technological quality of tetraploid wheat. Cer Chem 95:274-287

Tahir M, A Ali, MA Nadeem, A Hussain, F Khalid (2009). Effect of different sowing dates on growth and yield of wheat (Triticum aestivum L.) varieties in district Jhang, Pakistan. Pak Life Soc Sci 7:66-69

Talukder A, GK McDonald, GS Gill (2014). Effect of short-term heat stress prior to flowering and early grain set on the grain yield of wheat. Field Crops Res 160:54-63

Telfer P, J Edwards, D Bennett, D Ganesalingam, J Able, H Kuchel (2018). A field and controlled environment evaluation of wheat (Triticum aestivum) adaptation to heat stress. Field Crops Res 229:55-65

Ul-Allah S, M Iqbal, S Maqsood, M Naeem, M Ijaz, W Ashfaq, M Hussain (2018). Improving the performance of bread wheat genotypes by managing irrigation and nitrogen under semi-arid conditions. Arch Agron Soil Sci 64:1678-1689

Ul-Allah S, AA Khan, T Fricke, A Buerkert, M Wachendorf (2014). Fertilizer and irrigation effects on forage protein and energy production under semi-arid conditions of Pakistan. Field Crops Res 159:62-69

Ullah S, H Bramley, T Mahmood, R Trethowan (2020). A strategy of ideotype development for heat-tolerant wheat. J Agron Crop Sci 206:229-241

Viswanathan C, R Khanna-Chopra (2001). Effect of heat stress on grain growth, starch synthesis and protein synthesis in grains of whea (Triticum aestivum L.) varieties differing in grain weight stability. $J$ Agron Crop Sci 186:1-7

Wajid A, A Hussain, A Ahmad, AR Goheer, M Ibrahim, M Mussaddique (2004). Effect of sowing date and plant population on biomass, grain yield and yield components of wheat. Intl J Agric Biol 6:1003-1005

Whittal A, M Kaviani, R Graf, G Humphreys, A Navabi (2018). Allelic variation of vernalization and photoperiod response genes in a diverse set of North American high latitude winter wheat genotypes. PLoS One 13; Article e0203068

Yin L, X Dai, M He (2018). Delayed sowing improves nitrogen utilization efficiency in winter wheat without impacting yield. Field Crops Res 221:90-97

Zain M, I Khan, MU Chattha, RWK Qadri, SA Anjum, MU Hassan, A Mahmood, M Ilyas (2017). Foliar applied thiourea at different growth stages modulated late sown wheat. Pak J Sci 69:39-43 